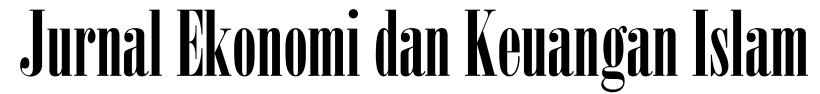

Available at https://journal.uii.ac.id/jeki

\section{Do stability and size affect the profitability of Islamic rural bank in Indonesia?}

\author{
Heri Sudarsono $^{1}$, Fiqih Afriadi ${ }^{2}$, Siti Aisiyah Suciningtias ${ }^{3}$ \\ ${ }^{1}$ Department of Economics, Faculty of Business and Economics, \\ Universitas Islam Indonesia, Yogyakarta, Indonesia \\ ${ }^{2}$ Department of Accounting, Faculty of Economics, Universitas Pamulang, Banten, Indonesia \\ ${ }^{3}$ Department of Management, Faculty of Economics, Universitas Islam Sultan Agung, \\ Semarang, Indonesia
}

\section{Article History}

Received : 22 June 2021

Revised : 27 June 2021

Accepted : 29 June 2021

Published : 1 July 2021

\section{Keywords:}

Profitability, stability, size, Generalized

Method of Moments (GMM).

DOI:

https://doi.org/10.20885/JEKI.vol7.iss 2.art5

JEL Clasification:

C23; G21; G32; L2

\section{Corresponding author:}

heri.sudarsono@uii.ac.id

Author's email:

lecturer01886@unpam.ac.id

aisiyah@unissula.ac.id

Paper type:

Research paper

Cite this article:

Sudarsono, H., Afriadi, F., \& Suciningtias, S. A. (2021). Do stability and size affect the profitability of Islamic rural bank in Indonesia?. Jurnal Ekonomi dan Keuangan Islam, 7(2), 161-174. https://doi.org/10.20885/JEKI.vol7.iss 2.art5

\section{Introduction}

Islamic rural bank (BPRS) is a bank that carries out business activities based on sharia principles. The business activities of BPRS include raising funds, providing financing, and placing funds in other banks. The role of BPRS in the community's economy increases along with the increasing number of BPRS from year to year. The number of BPRS in 2012 was only 158, which then increased to 164 in 2019 in 22 provinces. Meanwhile, the provinces with the highest number of 
BPRS is West Java with 29 BPRS, followed by East Java with 28 BPRS, Central Java with 26 BPRS, Yogyakarta with 12 BPRS, Lampung with 11 BPRS, and Banten with 8 BPRS. Along with increasing the reach of the BPRS in obtaining funding and financing, the assets of the BPRS have increased from year to year. In 2012 the value of assets reached IDR 4.697 billion, which then increased to IDR 13, 758 billion in 2019.

Increasing the assets of the BPRS increases the mobilization of funds to maximize profitability. Figure 1 shows the ROA from 2012 to 2019 in the range of $1.87 \%$ to $2.79 \%$. The ability of BPRS in optimizing assets to generate income from 2012 to 2019 is relatively stable. Although in 2018 the ROA value showed a value of $1.87 \%$, in 2019 the management of the BPRS was able to increase the revenue so that the value increased to $2.61 \%$. On the other hand, the ROE value shows a fluctuating value from 2012 to 2019. The highest ROE value occurred in 2019 with a value of $27.30 \%$ but the previous year showed the lowest ROE value from 2012 to 2019. BPRS's capital in generating income tends to be unstable.

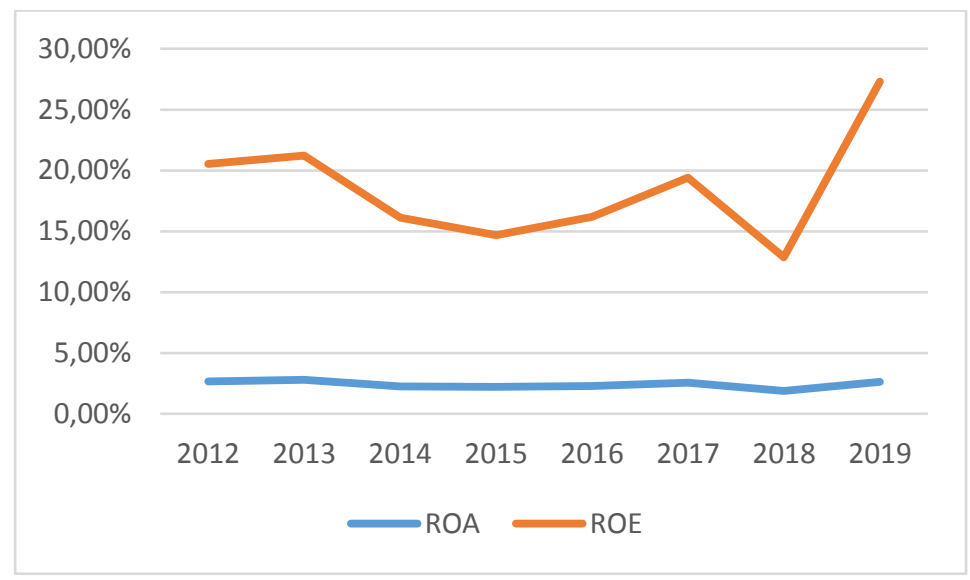

Figure 1. Growth of ROA and ROE for BPRS

Stability of financial performance and ownership of assets will increase the ability of banks to maximize financing to customers (Ali \& Puah, 2019). High bank stability and size will encourage BPRS to allocate funds in the form of financing. If the BPRS is able to optimize its financing, the BPRS has the potential to be able to maximize the expected profit. In various studies, financial performance is used as an instrument to compile the level of stability and size or value of bank assets. Several related studies include Ali and Puah (2019), and Le (2020) which examined the relationship between stability and profitability in banking. Meanwhile, Azoury et al. (2018), Zouari and Taktak (2014), Boussaada and Karmani (2015), Dietrich and Wanzenried (2014), Tan (2016), and Tan and Floros, (2012) examined the relationship between size and bank profitability.

Research on the relationship between stability and bank size on the profitability of BPRS has not been widely studied in Indonesia. However, bank stability and size are recognized as an important factor in influencing profitability. Several studies have begun to include stability and size as part of the research model, such as Amanda et al. (2020) which includes size as a control variable, the study was conducted on 93 banks from 2012 to 2018, with the results showing that size has a positive effect on profitability. In line with Sijabat et al. (2020) with a research object of 42 banks listed on the Indonesia Stock Exchange (IDX), found a negative relationship between size and profitability. Meanwhile, Fithria (2018) conducted research on 115 BPRS in Indonesia and found that the size of the BPRS has an effect on profitability.

A number of previous studies examined the relationship between bank size and profitability in conventional and Islamic banks in Indonesia and abroad. However, from these studies, it is still rare to find research on the effect of stability and size on profitability in BPRS. By considering the importance of research examining the relationship between stability and bank size on profitability in a BPRS, this study tries to analyze the effect of stability and size on profitability in BPRS. Size and stability as the main variables that affect profitability, while bank-specific variables and macroeconomic variables become control variables in the research model. 


\section{Literature Review}

The Z-score (STAB) used as the dependent variable is a proxy for the stability of the bank's performance as measured by the total ROA and CAR divided by the standard deviation of the ROA. In addition, the Z-score is used to measure bank's default and assess its bankruptcy (Demirgiic \& Huizinga, 1999; Khan et al., 2017; Mokni et al., 2016). Z score is also used to measure the ability of capital and income to cover losses in a certain period (Lepetit \& Strobel, 2015). The ability of banks to optimize assets to generate income consistently will increase bank stability. However, stability will decline if the bank does not consistently earn income. The bank's efforts to maintain the trend of income from year to year become one of the challenges for management in maintaining stability. High stability will increase the bank's ability to generate profitability on an ongoing basis. A number of studies have found mixed relationships between bank stability and profitability in several countries. Ali and Puah (2019) found a positive relationship between stability and profitability in 24 commercial banks in Pakistan. Likewise, Le (2020) finds that stability has a positive effect on profitability in Vietnam. From the explanation above, the following hypothesis can be formulated:

$\mathrm{H}_{1}$ : The level of stability has a positive effect on the profitability of the BPRS

Bank size (SIZE) is a proxy for the total assets owned by the bank (Azoury et al., 2018; Bougatef, 2017; Lee \& Isa, 2017). Banks with large asset sizes tend to generate higher profitability because banks have more opportunities to diversify their profitable portfolios. Banks have a higher potential to generate income if they have a lot of assets (Athanasoglou et al., 2008). However, bank's management is required to be able to utilize assets in order to avoid inefficiencies. A high value of assets have an impact on the maintenance cost and tax burden. Therefore, higher assets require management to be able to manage these assets to generate maximum income. A number of studies have found mixed results between size and profitability. Research by Boussaada and Karmani (2015) on 38 commercial banks in MENA found that size had a positive effect on profitability. However, Zouari and Taktak (2014) found that size had no effect on profitability at 53 banks in 15 Islamic countries. Tan and Floros (2012) found that size had no effect on profitability in 101 banks in China. Meanwhile, Azoury et al. (2018) found a negative effect between bank size on profitability in 35 banks in Lebanon. Likewise, Tan (2016) found that size had a negative effect on profitability in China and Javaid et al. (2011) found a negative effect on the top 10 banks in India. From the previous findings, the relationship between size and the profitability of a BPRS can be drawn up as follows:

$\mathrm{H}_{2}$ : The size has a positive/negative effect on the profitability of the BPRS

Liquidity level (BAC) is the ratio of total financing to total assets. Liquidity is used to calculate the bank's ability to use assets to generate profitability. A high level of liquidity has the potential to generate high profitability. On the other hand, poor financing distribution will increase nonperforming financing. Hapsari and Rokhim (2017), and Trujillo-Ponce (2013) found a positive influence between liquidity and profitability. Meanwhile, Davydenko (2011) found a negative relationship between liquidity and profitability. Then, the capital structure (CS) is the ratio between shareholder equity divided by total assets. Capital structure shows the ability of shareholders to anticipate bank risk within a certain period. Banks that have high CS will have more ability to anticipate financial risks. A high CS will increase the ability of management to channel liquidity to potential sources of income. However, an increase in CS that is not followed by efforts to become a liquidity balance causes profitability to decline (Sun et al., 2017). Tan (2016) and Trujillo-Ponce (2013) found that CS has a positive effect on profitability. Meanwhile, Westman (2013) found a negative relationship between CS and profitability. From the discussion above, the following hypotheses can be formulated:

$\mathrm{H}_{3}$ : The level of liquidity has a positive/negative effect on the profitability of the BPRS $\mathrm{H}_{4}$ : The level of capital structure has a positive/negative effect on profitability of the BPRS

Operational efficiency (OE) indicates the bank's ability to utilize operating income to cover operational costs. The higher operating costs on operating income will have a negative impact on 
profitability (Dietrich \& Wanzenried, 2011; Trujillo-Ponce, 2013; Yao et al., 2018; Zarrouk et al., 2016). Meanwhile, the deposit structure (DS) or the ratio of funding to equity is used as a proxy for the deposit structure. The increase in funds flowing in the bank will encourage an increase in the ability of banks to generate profitability (García-Herrero et al., 2009). Yao et al. (2018) found a positive effect between deposit structure on bank profitability. On the other hand, financing to debt ratio (FDR) or liquidity can be defined as the ability to meet cash needs (cash flow) immediately and at an appropriate cost. The results of the research by Yudha et al. (2017) and Widarjono (2018) show that liquidity (FDR) has a positive effect on the profitability of Islamic banks. However, Dewi and Sudarsono (2021), and Said and Ali (2016) found that FDR had no effect on profitability. Meanwhile, the Deposit to Asset Ratio (DAR) is a comparison between the value of deposits and the total assets owned by the bank (Bateni et al., 2014). The DAR level indicates the ability of incoming funds to be utilized to generate income. A high DAR has an opportunity for banks to use their funds to generate profitability. However, Bateni et al. (2014), and Hapsari and Rokhim (2017) found that DAR had no effect on profitability. From a number of studies above, the following hypotheses can be formulated:

$\mathrm{H}_{5}$ : The level of operational efficiency has a negative effect on the profitability of the BPRS

$\mathrm{H}_{6}$ : The level of deposit structure has a positive effect on the profitability of the BPRS

$\mathrm{H}_{7}$ : The level of financing to debt ratio has a positive effect on the profitability of the BPRS

$\mathrm{H}_{8}$ : The level of deposit to asset ratio has a positive effect on the profitability of the BPRS

Meanwhile, an increase in economic growth (GDP) will encourage increased financing thereby increasing opportunities to generate income. A number of studies have found a positive relationship between economic growth and profitability (Dietrich \& Wanzenried, 2011; Sinha \& Sharma, 2016; Trujillo-Ponce, 2013). However, Fithria (2018) shows that there is no effect between economic growth and the profitability of BPRS in Indonesia. Meanwhile, an increase in inflation will increase production costs, thereby reducing financing (Sudarsono, 2017a). The decline in the value of financing will reduce the potential for banks to generate maximum income. Research by Djalilov and Piesse (2016), Lee et al. (2015), Sudarsono (2017b), Zarrouk et al. (2016) found a negative relationship between inflation (INF) and profitability. While Aslam and Ijaz (2016), Chokri and Anis (2018), Fithria (2018), and Tumewang et al. (2019) find that inflation does not statistically affect bank's profitability. The hypothesis of the relationship between the growth rate and the inflation rate on the profitability of a BPRS can be arranged as follows:

$\mathrm{H}_{9}$ : The rate of economic growth has a positive effect on the profitability of the BPRS $\mathrm{H}_{10}$ : The inflation rate has a negative effect on the profitability of the BPRS

\section{Methodology}

This study uses a dynamic panel data model to determine the determinants of bank stability and size on the profitability of a BPRS. The panel data consists of 82 BPRS from December 2012 to December 2019. The limitations of the data obtained are the reason for this study using 82 BPRS with 574 observations for 7 years. Data on profitability, stability, size, and bank-specific variables were obtained from the statistical report of the Financial Services Authority (OJK) in 2021. Meanwhile, data on economic growth and inflation were taken from the Central Bureau of Statistics (BPS). Definitively the variables used in this study are profitability variables; ROA and ROE, Stability (STAB), Size (SZ), liquidity (BAC), size (SZ), capital structure (CS), operational efficiency $(\mathrm{OE})$, deposit structure (DS), financing to deposit ratio (FDR), Deposit to asset ratio (DAR), economic growth (GDP) and inflation (INF). Variable descriptions and research hypotheses can be described in Table 1.

The panel data is then applied to the dynamic panel data model. The dynamic model was chosen because it is understood that the relationship among economic variables is unstable. In other words, economic variables are not only determined from the current economic condition variable, but also determined by the time variable in the previous period. (Yao et al., 2018). Therefore, the application of a dynamic data model is considered more appropriate to be used in 
describing actual conditions in economic analysis. Furthermore, the research model used in this study is the GMM (General Method of Moments) estimator developed by Arellano and Bover, (1995) dan Blundell and Bond, (1998).

Table 1. Variables of Study with Hypothesis

\begin{tabular}{|c|c|c|c|}
\hline Name & Symbol & Variable definition & Source \\
\hline Profitability & $\begin{array}{l}\text { ROA } \\
\text { ROE }\end{array}$ & $\begin{array}{l}\text { Return on Aset } \\
\text { Return on Equity }\end{array}$ & \\
\hline STAB & STAB & $\begin{array}{l}\text { Sum of ROA and CAR } \\
\text { divided by standard } \\
\text { deviation of ROA }\end{array}$ & Ali and Puah (2019); Le (2020) \\
\hline Size & SZ & Logarithm of total aset & $\begin{array}{l}\text { Boussaada and Karmani, (2015); Zouari } \\
\text { and Taktak (2014); Tan and Floros (2012); } \\
\text { Azoury et al. (2018); Tan (2016); Javaid et } \\
\text { al. (2011) }\end{array}$ \\
\hline Liquidity & $\mathrm{BAC}$ & $\begin{array}{l}\text { Total financing to total } \\
\text { asset }\end{array}$ & $\begin{array}{l}\text { Trujillo-Ponce (2013); Davydenko (2011); } \\
\text { Hapsari and Rokhim (2017) }\end{array}$ \\
\hline Capital Structure & CS & $\begin{array}{l}\text { Total equity to total } \\
\text { asset }\end{array}$ & $\begin{array}{l}\text { Sun et al. (2017); Tan (2016); Trujillo- } \\
\text { Ponce (2013); Westman (2013) }\end{array}$ \\
\hline $\begin{array}{l}\text { Operational } \\
\text { Efficiency }\end{array}$ & $\mathrm{OE}$ & $\begin{array}{l}\text { Total operating expenses } \\
\text { to gross income. }\end{array}$ & $\begin{array}{l}\text { Dietrich and Wanzenried, (2011); Trujillo- } \\
\text { Ponce, (2013); Yao et al. (2018); Zarrouk et } \\
\text { al. (2016). }\end{array}$ \\
\hline Deposit Structure & DS & $\begin{array}{l}\text { Total deposits to total } \\
\text { equity }\end{array}$ & $\begin{array}{l}\text { García-Herrero et al. (2009); Yao et al. } \\
\text { (2018) }\end{array}$ \\
\hline $\begin{array}{l}\text { Financing to } \\
\text { deposit rasio }\end{array}$ & FDR & $\begin{array}{l}\text { Total financing to total } \\
\text { deposit }\end{array}$ & $\begin{array}{l}\text { Yudha et al (2017); Widarjono (2018); } \\
\text { Dewi and Sudarsono (2021) }\end{array}$ \\
\hline $\begin{array}{l}\text { Deposit to asset } \\
\text { ratio }\end{array}$ & DAR & $\begin{array}{l}\text { Total Funding to total } \\
\text { aset }\end{array}$ & $\begin{array}{l}\text { Bateni et al. (2014); Hapsari and Rokhim } \\
\text { (2017) }\end{array}$ \\
\hline Economic Growth & GDP & $\begin{array}{l}\text { Logarithm of Gross } \\
\text { Domestic Product }\end{array}$ & $\begin{array}{l}\text { Dietrich and Wanzenried (2011); Sinha and } \\
\text { Sharma (2016); Trujillo-Ponce, 2013); } \\
\text { Fithria (2018) }\end{array}$ \\
\hline Inflation & INF & Inflation rate & $\begin{array}{l}\text { Djalilov and Piesse (2016); Lee et al. (2015); } \\
\text { Sudarsono (2017b); Zarrouk et al. (2016); } \\
\text { Aslam and Ijaz (2016); Chokri and Anis } \\
\text { (2018); Fithria, (2018); Tumewang et al. 2019) }\end{array}$ \\
\hline
\end{tabular}

This model is also known as the system GMM estimator. The use of the system GMM estimator model is considered the most appropriate model due to endogeneity issues and the possibility of unobserved individual-specific effects that are not included in the model. Furthermore, in this study, the number of observation times ( $\mathrm{t}$ ) used is less than the number of observations so that using the GMM estimation is considered to be able to produce an unbiased and consistent estimate (Roodman, 2009). The two-step GMM estimation procedure is considered to be the most suitable method which provides less biased coefficient estimates and more robust and efficient estimation results than the one-step GMM system (Roodman, 2009; Windmeijer, 2005).

This research model is a development of the research model of Ahamed (2017), Athanasoglou et al. (2008), Bougatef (2017), Dietrich and Wanzenried (2011) Lee and Isa (2017), Tan (2016), Trujillo-Ponce (2013), Yanikkaya et al. (2018), Yao et al. (2018), and Zarrouk et al. (2016). This research includes variables of stability (STAB), size (SZ), liquidity (BAC), size (SZ), capital structure (CS), operational efficiency (OE), deposit structure (DS), financing to deposit ratio (FDR), Deposit to asset ratio (DAR), economic growth (GDP) and inflation (INF) as determinant variables of profitability (ROA and ROE). From a number of these studies, it can be formulated that the model of the influence of stability and size on the profitability of a BPRS is as follows; 
$R O A=\partial+\beta_{1} R O A_{i t-1}+\beta_{2} S T A B_{i t}+\beta_{3} S Z_{i t}+\beta_{4}$ SPECIFIC $_{i t}+\beta_{5}$ MACRO $_{i t}+\Phi X_{i t}+\varepsilon_{i t}$ $R O E=\partial+\beta_{1} R O E_{i t-1}+\beta_{2} S T A B_{i t}+\beta_{3} S Z_{i t}+\beta_{4}$ SPECIFIC $_{i t}+\beta_{5} M A C R O_{i t}+\Phi X_{i t}+\varepsilon_{i t}$

where the subscripts $i$ and $t$ refer to the BPRS and year, respectively, ROA and ROE are the profitability of the BPRS. SPECIFIC is a bank-specific variable consisting of capital structure (CS), operational efficiency (OE), deposit structure (DS), financing to deposit ratio (FDR), Deposit to asset ratio (DAR). While MACRO is a macroeconomic control variable, such as economic growth (GDP) and inflation (INF). Furthermore, the use of lagged period $t-n$ is in accordance with what was initiated by Roodman (2009) in the estimation of the dynamic panel data model using the Generalized Method of Moments (GMM). The use of lagged ROA and ROE for the t-1 period is adjusted to the use of the appropriate model, where there is a significant autocorrelation in the first and second lags, but in the third lag and so on it is not significant so it is not suitable to be used in this research model.

\section{Result}

Table 2 shows the descriptive statistics of the variables used in this study. The ROA value is between -0.085 and 4.801 with a standard deviation of 0.2375 , while the ROE value is between 42.9974 and 8.8253 with a standard deviation of 2.0809 . The risk standard deviation is 0.9002 with an average value of 2.0291 , a minimum value of 0.0178 , and a maximum of 10.8533 . The size of the BPRS ranges from 10.2076 to 20.9207, the liquidity of the BPRS is between 0.0001 and 11.1594 . NTA ranges between -0.7153 and 3.2717, a capital structure (CS) ranges between $-0,4374$ and 9,2683, and operational efficiency ranges between 0.0001 and 10,2399. The deposit structure has a minimum value of $-106,4453$ and a maximum of 19,3167, economic growth (GDP) has a minimum value of 15,7418 with a maximum value of 16,1597 , and inflation has a minimum value of 0.420 and a maximum value of 2.460 .

Tabel. 2. Descriptive Statistics

\begin{tabular}{llrrrr}
\hline \multicolumn{1}{c}{ Variable } & Obs & \multicolumn{1}{c}{ Mean } & Std. Dev. & \multicolumn{1}{c}{ Min } & \multicolumn{1}{c}{ Max } \\
\hline ROA & 574 & 0.1959 & 0.2375 & -0.0855 & 4.8012 \\
ROE & 574 & 1.3235 & 2.0809 & -42.9974 & 8.8253 \\
STAB & 574 & 2.0291 & 0.9002 & 0.0178 & 10.8533 \\
SIZE & 574 & 17.1236 & 1.3599 & 10.2076 & 20.9208 \\
BAC & 574 & 0.1164 & 0.4741 & 0.0001 & 11.1595 \\
CS & 574 & 0.1963 & 0.43947 & -0.4375 & 9.2684 \\
OE & 573 & 0.6758 & 0.58671 & 0.0006 & 10.2399 \\
DS & 572 & 3.6680 & 5.6838 & -106.4453 & 19.3167 \\
FDR & 574 & 0.6502 & 1.6848 & 0.0001 & 16.4309 \\
DAR & 574 & 0.5079 & 1.0379 & 0.0001 & 24.1212 \\
GDP & 574 & 16.0101 & 0.0998 & 15.7418 & 16.1597 \\
INF & 574 & 0.8943 & 0.6589 & 0.4200 & 2.4600 \\
\hline
\end{tabular}

\section{Validity Test}

After analyzing descriptive statistics and before estimating the GMM model, a separate empirical test was conducted by dividing it into ROA and ROE. Table 3 shows several model specifications to get the best model that can represent the best results in the model. To find the best model, it must meet several criteria, namely a consistent estimator, a valid instrument, and an unbiased estimator. The consistency of the estimator is shown by the results of the Arellano-Bond (AB) estimation. The estimation results of $\mathrm{AB}$ in the $\mathrm{ROA}$ equation model indicated by the statistical value of $\mathrm{m} 2$ in all models showed that it was not significant at 5 or 10 percent. While the ROE equation model shows that $\mathrm{m} 2$ is not significant in model $1,2,3,4,5$ and 6 at 5 or 10 percent, while the M2 significance value indicates that all models are not significant. From these results, it can be stated that all models of ROA equations in model 1, 2, 3, 4, 5, and 6, as well as models of ROE equations in model 1,2, 3, 4, 5 and 6 can be stated to be consistent and there is no autocorrelation. on the second-order first difference error. 
Then, the validity of the instrument can be checked with the Sargan test. The statistical value of the Sargan test on the ROA equation model shows that model 1, 4 and 6 are not significant at 5 or 10 percent. Meanwhile, the ROE equation model for model 1, 2, 3, 4, 5, and 6, shows nonsignificant results at 5 or 10 percent. These results indicate that model 1, 4, and 6 in the ROA equation model and model 1,2, 3, 4, 5, and 6 in the ROE equation model, there is no correlation between residues and over-identifying restrictions or the instrument used is more of the estimated number of parameters so that it can be said that the instrument is valid. From the results of the Arellano-Bond (AB) test and the Sargan test, it can be seen that the models that meet the criteria for consistent estimators and valid instruments are model 1, 4 and 6 in the ROA equation, as well as model 1, 2, 3, 4, 5, and 6 in ROE equation.

Table 3. Test Specifications

\begin{tabular}{|c|c|c|c|c|c|c|}
\hline & $(1)$ & (2) & (3) & (4) & (5) & (6) \\
\hline \multicolumn{7}{|c|}{ ROA Equation Model } \\
\hline AB Test-m1 & -1.3912 & -1.1145 & -1.2229 & -1.4015 & -1.0579 & -1.3849 \\
\hline Prob $>z$ & 0.1642 & 0.2650 & 0.2214 & 0.1611 & 0.2901 & 0.1661 \\
\hline AB Test-m2 & .25738 & .96855 & .20066 & .2269 & .9447 & .26221 \\
\hline Prob $>z$ & 0.7969 & 0.3328 & 0.8410 & 0.8205 & 0.3448 & 0.7932 \\
\hline Sargan Test-Chi2 & 24.67594 & 43.09177 & 29.93474 & 24.1943 & 30.77948 & 24.78473 \\
\hline Prob $>$ chi2 & 0.1715 & 0.0013 & 0.0526 & 0.1888 & 0.0427 & 0.1678 \\
\hline \multicolumn{7}{|c|}{ ROE Equation Model } \\
\hline AB Test-m1 & -2.0456 & -1.982 & -1.0231 & -1.0222 & -1.9355 & -2.101 \\
\hline Prob $>z$ & 0.0408 & 0.0475 & 0.3063 & 0.3067 & 0.0529 & 0.0356 \\
\hline AB Test-m2 & -.13475 & -.57048 & -1.4329 & -1.44 & -.58385 & -.1462 \\
\hline Prob $>z$ & 0.8928 & 0.5684 & 0.1519 & 0.1499 & 0.5593 & 0.8838 \\
\hline Sargan Test-Chi2 & 24.17097 & 17.52537 & 20.67093 & 19.49901 & 19.1539 & 24.30359 \\
\hline Prob >chi2 & 0.1897 & 0.5543 & 0.3553 & 0.4253 & 0.4470 & 0.1848 \\
\hline
\end{tabular}

Tabel 4. Empirical results of BPRS's profitability regression models: (ROA)

\begin{tabular}{|c|c|c|c|c|c|c|}
\hline & (1) & (2) & (3) & (4) & (5) & (6) \\
\hline L.ROA & $\begin{array}{c}0.0185^{* * *} \\
(10.82)\end{array}$ & $\begin{array}{c}-0.0172^{* * *} \\
(-13.23)\end{array}$ & $\begin{array}{c}0.0110^{* * *} \\
(8.68)\end{array}$ & $\begin{array}{c}0.0192^{* * *} \\
(10.74)\end{array}$ & $\begin{array}{c}-0.0102^{* * *} \\
(-12.24)\end{array}$ & $\begin{array}{c}0.0194^{* * *} \\
(11.34)\end{array}$ \\
\hline STAB & $\begin{array}{c}-0.0310^{* * *} \\
(-9.32)\end{array}$ & $\begin{array}{c}-0.0415^{* * *} \\
(-5.12)\end{array}$ & $\begin{array}{c}-0.0336^{* * *} \\
(-9.36)\end{array}$ & $\begin{array}{c}-0.0325^{* * *} \\
(-10.33)\end{array}$ & $\begin{array}{c}-0.0353^{* * *} \\
(-6.32)\end{array}$ & $\begin{array}{c}-0.0321^{* * *} \\
(-9.28)\end{array}$ \\
\hline SIZE & $\begin{array}{c}-0.0704^{* * *} \\
(-11.73)\end{array}$ & $\begin{array}{c}-0.0995^{* * *} \\
(-21.22)\end{array}$ & $\begin{array}{c}-0.0628^{* * *} \\
(-11.41)\end{array}$ & $\begin{array}{c}-0.0706^{* * *} \\
(-11.70)\end{array}$ & $\begin{array}{c}-0.0812^{* * *} \\
(-27.07)\end{array}$ & $\begin{array}{c}-0.0721^{* * *} \\
(-12.13)\end{array}$ \\
\hline $\mathrm{BAC}$ & $\begin{array}{c}-0.868^{* * *} \\
(-26.20)\end{array}$ & $\begin{array}{l}0.368^{* * *} \\
(39.86)\end{array}$ & $\begin{array}{c}-0.827^{* * *} \\
(-20.53)\end{array}$ & $\begin{array}{c}-0.874^{* * *} \\
(-25.38)\end{array}$ & & $\begin{array}{l}-0.860^{* * *} \\
(-25.76)\end{array}$ \\
\hline CS & $\begin{array}{c}0.00482 \\
(0.27)\end{array}$ & $\begin{array}{c}0.0922^{* * *} \\
(3.40)\end{array}$ & $\begin{array}{c}0.00328 \\
(0.17)\end{array}$ & $\begin{array}{c}0.00447 \\
(0.25)\end{array}$ & & $\begin{array}{c}0.00620 \\
(0.34)\end{array}$ \\
\hline $\mathrm{EO}$ & $\begin{array}{c}-0.00784 \\
(-1.76)\end{array}$ & $\begin{array}{c}-0.00345 \\
(-0.65)\end{array}$ & $\begin{array}{c}-0.0110 \\
(-1.83)\end{array}$ & & $\begin{array}{c}-0.0105^{*} \\
(-2.28)\end{array}$ & $\begin{array}{c}-0.00796 \\
(-1.85)\end{array}$ \\
\hline DS & $\begin{array}{c}0.000197 \\
(0.15)\end{array}$ & $\begin{array}{c}-0.000370^{* *} \\
(-2.93)\end{array}$ & & & $\begin{array}{c}0.0000398 \\
(0.09)\end{array}$ & $\begin{array}{c}0.000191 \\
(0.15)\end{array}$ \\
\hline FDR & $\begin{array}{c}0.0362^{* * *} \\
(5.78)\end{array}$ & $\begin{array}{c}-0.00821 \\
(-1.57)\end{array}$ & & $\begin{array}{c}0.0372^{* * *} \\
(5.93)\end{array}$ & $\begin{array}{c}0.00584 \\
(1.78)\end{array}$ & $\begin{array}{c}0.0367^{* * *} \\
(5.49)\end{array}$ \\
\hline DAR & $\begin{array}{c}0.593^{* * *} \\
(34.63)\end{array}$ & & $\begin{array}{c}0.575^{* * *} \\
(28.51)\end{array}$ & $\begin{array}{c}0.596^{* * *} \\
(33.54)\end{array}$ & $\begin{array}{l}0.202^{* * *} \\
(271.95)\end{array}$ & $\begin{array}{l}0.589^{* * *} \\
(33.96)\end{array}$ \\
\hline GDP & $\begin{array}{c}-0.0155 \\
(-0.73)\end{array}$ & $\begin{array}{c}0.0195 \\
(1.12)\end{array}$ & $\begin{array}{c}-0.0281 \\
(-1.31)\end{array}$ & $\begin{array}{c}-0.0152 \\
(-0.71)\end{array}$ & $\begin{array}{c}0.00567 \\
(0.41)\end{array}$ & \\
\hline INF & $\begin{array}{c}0.000692 \\
(0.25)\end{array}$ & $\begin{array}{c}-0.00892^{* * *} \\
(-4.72)\end{array}$ & $\begin{array}{c}0.00182 \\
(0.69)\end{array}$ & $\begin{array}{c}0.00111 \\
(0.41)\end{array}$ & $\begin{array}{c}-0.00179 \\
(-1.09)\end{array}$ & \\
\hline _CONS & $\begin{array}{c}1.482^{* * *} \\
(4.38)\end{array}$ & $\begin{array}{c}1.637^{* * *} \\
(5.63)\end{array}$ & $\begin{array}{c}1.577^{* * *} \\
(4.69)\end{array}$ & $\begin{array}{c}1.481^{* * *} \\
(4.32)\end{array}$ & $\begin{array}{c}1.461^{* * *} \\
(6.80)\end{array}$ & $\begin{array}{l}1.266^{* * *} \\
(11.01)\end{array}$ \\
\hline
\end{tabular}

$t$ statistics in parentheses

${ }^{*} p<0.05,{ }^{* *} p<0.01,{ }^{* * *} p<0.001$ 
The ROA equation model in model 1, 4 and 6 in Table 4 shows that stability (STAB), BPRS size (SIZE), and liquidity (BAC) have a negative effect on ROA in all equation models except in equation model 2 which shows BAC has a positive effect on ROA. While DS is known to have a positive effect on ROA in the equation model 2, but it is not significant in the other 5 equation models. CS does not show a significant value in all equation models to ROA except in equation 2. FDR shows a positive relationship in all equation models except in equation 2 and 5. While DAR is known to be positively related to ROA in all equations. The macro variables of economic growth (GDP) and inflation (INF) do not show a significant relationship to ROA, except for the model equation 2 which shows a negative relationship between inflation and ROA.

Table 5 shows the results of the ROE equation model data processing in model 3 and 4 showing financial stability (STAB), BPRS size (SIZE), capital structure (CS), operational efficiency (EO) and total deposit (DAR) negatively related to ROE, but in equation 3 the value of $\mathrm{EO}$ is not significant at $\mathrm{p}=5 \%$. The effect of liquidity $(\mathrm{BAC})$ on $\mathrm{ROE}$ is different from ROA, BAC has a positive effect on $\mathrm{ROE}$, but equation 12 shows that $\mathrm{BAC}$ has a negative effect on $\mathrm{ROE}$. As for the deposit structure (DS), the ratio of financing to funding (FDR) and inflation (INF) shows a positive relationship to ROE at $\mathrm{p}=5 \%$. Meanwhile, economic growth does not show any effect on ROE.

Table. 5 Empirical results of BPRS's profitability regression models: (ROE)

\begin{tabular}{|c|c|c|c|c|c|c|}
\hline & (1) & (2) & (3) & (4) & (5) & (6) \\
\hline L.ROE & $\begin{array}{c}0.0129^{* * *} \\
(10.23)\end{array}$ & $\begin{array}{c}0.00807^{* * *} \\
(6.28)\end{array}$ & $\begin{array}{c}-0.0228^{* * *} \\
(-12.40)\end{array}$ & $\begin{array}{c}-0.0236^{* * *} \\
(-13.02)\end{array}$ & $\begin{array}{c}0.00778^{* * *} \\
(6.37)\end{array}$ & $\begin{array}{c}0.0140^{* * *} \\
(11.04)\end{array}$ \\
\hline STAB & $\begin{array}{c}-0.0882^{* *} \\
(-2.77)\end{array}$ & $\begin{array}{c}-0.113^{* * *} \\
(-3.77)\end{array}$ & $\begin{array}{c}-0.387^{* * *} \\
(-6.07)\end{array}$ & $\begin{array}{c}-0.378^{* * *} \\
(-5.89)\end{array}$ & $\begin{array}{c}-0.113^{* * *} \\
(-3.77)\end{array}$ & $\begin{array}{c}-0.107^{* * *} \\
(-3.39)\end{array}$ \\
\hline SIZE & $\begin{array}{c}-0.306^{* * *} \\
(-4.84)\end{array}$ & $\begin{array}{c}-0.169^{* *} \\
(-3.09)\end{array}$ & $\begin{array}{c}-0.186^{* *} \\
(-3.25)\end{array}$ & $\begin{array}{c}-0.202^{* * *} \\
(-3.49)\end{array}$ & $\begin{array}{c}-0.216^{* * *} \\
(-3.86)\end{array}$ & $\begin{array}{c}-0.337^{* * *} \\
(-5.21)\end{array}$ \\
\hline $\mathrm{BAC}$ & $\begin{array}{c}2.513^{* * *} \\
(7.96)\end{array}$ & $\begin{array}{c}-0.0588^{* *} \\
(-2.84)\end{array}$ & $\begin{array}{c}1.365^{* * *} \\
(6.68)\end{array}$ & $\begin{array}{l}1.429^{* * *} \\
(6.81)\end{array}$ & & $\begin{array}{l}2.570^{* * * *} \\
(8.01)\end{array}$ \\
\hline CS & $\begin{array}{c}0.0575 \\
(1.09)\end{array}$ & $\begin{array}{c}-0.0135 \\
(-0.42)\end{array}$ & $\begin{array}{c}-0.0962^{* * *} \\
(-7.16)\end{array}$ & $\begin{array}{c}-0.0966^{* * *} \\
(-6.57)\end{array}$ & & $\begin{array}{c}0.0385 \\
(0.77)\end{array}$ \\
\hline $\mathrm{EO}$ & $\begin{array}{c}-0.249^{* * *} \\
(-3.89)\end{array}$ & $\begin{array}{l}-0.206^{* *} \\
(-3.13)\end{array}$ & $\begin{array}{c}-0.0204 \\
(-0.37)\end{array}$ & & $\begin{array}{c}-0.214^{* *} \\
(-3.23)\end{array}$ & $\begin{array}{c}-0.219^{* *} \\
(-3.26)\end{array}$ \\
\hline DS & $\begin{array}{l}0.391^{* * *} \\
(248.99)\end{array}$ & $\begin{array}{c}0.385^{* * *} \\
(110.33)\end{array}$ & & & $\begin{array}{l}0.387^{* * *} \\
(130.07)\end{array}$ & $\begin{array}{c}0.391^{* * *} \\
(261.90)\end{array}$ \\
\hline FDR & $\begin{array}{c}0.0449 \\
(1.00)\end{array}$ & $\begin{array}{l}0.122^{* *} \\
(3.21)\end{array}$ & & $\begin{array}{c}-0.0430 \\
(-1.61)\end{array}$ & $\begin{array}{l}0.118^{* *} \\
(3.10)\end{array}$ & $\begin{array}{c}0.0467 \\
(1.03)\end{array}$ \\
\hline DAR & $\begin{array}{c}-1.223^{* * *} \\
(-8.38)\end{array}$ & & $\begin{array}{c}-0.648^{* * *} \\
(-6.97)\end{array}$ & $\begin{array}{c}-0.680^{* * *} \\
(-7.10)\end{array}$ & $\begin{array}{c}-0.0505^{*} \\
(-2.08)\end{array}$ & $\begin{array}{c}-1.249^{* * *} \\
(-8.43)\end{array}$ \\
\hline GDP & $\begin{array}{l}0.137 \\
(0.86)\end{array}$ & $\begin{array}{c}0.0196 \\
(0.12)\end{array}$ & $\begin{array}{c}-0.0598 \\
(-0.38)\end{array}$ & $\begin{array}{l}-0.0570 \\
(-0.36)\end{array}$ & $\begin{array}{c}0.0116 \\
(0.07)\end{array}$ & \\
\hline INF & $\begin{array}{c}0.0221 \\
(1.55)\end{array}$ & $\begin{array}{c}0.0335^{*} \\
(2.02)\end{array}$ & $\begin{array}{c}0.0309 \\
(1.92)\end{array}$ & $\begin{array}{c}0.0264 \\
(1.58)\end{array}$ & $\begin{array}{c}0.0359^{*} \\
(2.13)\end{array}$ & \\
\hline _CONS & $\begin{array}{l}3.579 \\
(1.33)\end{array}$ & $\begin{array}{l}2.839 \\
(1.07)\end{array}$ & $\begin{array}{l}6.471^{*} \\
(2.27)\end{array}$ & $\begin{array}{l}6.702^{*} \\
(2.32)\end{array}$ & $\begin{array}{l}3.783 \\
(1.40)\end{array}$ & $\begin{array}{c}6.378^{* * *} \\
(5.76) \\
\end{array}$ \\
\hline
\end{tabular}

$t$ statistics in parentheses

${ }^{*} p<0.05,{ }^{* *} p<0.01,{ }^{* * *} p<0.001$

\section{Discussion}

The results of the research show that the level of stability of the BPRS has a negative effect on the profitability of the BPRS as measured by ROA and ROE. This result is not in accordance with the findings of Ali and Puah, (2019) and Le, (2020) which confirm that there is a positive relationship between stability and profitability. This negative result shows that the management of the BPRS has not been able to maximize its assets to be channeled into potential financing. BPRS generally obtains income from the company's core business in the form of margin or profit-sharing from the distribution of bank funds. To earn income from non-core businesses, a strong bank infrastructure is needed, supported by reliable technology and human resources. This condition 
creates the dependence of BPRS on the economic and business conditions of its customers. Hence, it is important for BPRS to create more varied types of financing disbursed so that they are not dominated by only one type of financing to increase their income. On the other hand, the management's cautious attitude in disbursing financing is one of the reasons the income earned is inconsistent. This prudence will reduce the use of funds which will cause the BPRS to become over liquid. Overliquidity will increase the ratio of the cost of funds to the assets of the BPRS so that the burden on the BPRS will increase and reduce the ability of the BPRS to increase revenue. If the income of the BPRS is inconsistent, the stability of the BPRS will also decrease and this situation will affect the chances of the BPRS to optimize its profitability.

Size (SZ) is negatively related to the profitability of the BPRS. Assets that are not utilized optimally will become a financial burden for the BPRS, resulting in inefficient financial performance. These results support the research of Azoury et al. (2018), Javaid et al. (2011), and Tan (2016) who found a negative relationship between size and profitability. The negative influence between size and profitability can be caused by diseconomies of scale, namely managerial inefficiency that comes with the greater the bank's assets and the more complex the problems faced (Javaid et al., 2011). This situation was caused by managerial caution in disbursing financing due to long-term economic considerations. This is done to avoid potential non-performing financing in the future. However, this attitude reduces the consistency of the BPRS to maximize profitability each period. The negative effect of bank size on profitability can also occur because small banks are however better able to form closer relationships with their customers, allowing them to access better information, especially in creditworthiness decisions and setting contract terms (Kosmidou, 2011). This advantage of information and pricing allows small banks to generate better profits than large banks so that they are able to offset the losses of economies of scale.

The ability of BPRS in allocating financing on assets (BAC) is negatively related to ROA, but positively related to ROE. This situation shows that the BPRS has not optimally channeled its financing to generate the targeted income. On the other hand, the ratio of disbursed financing to financing returns from investors tends to increase, causing financing risk to increase. The negative and significant effect of the $\mathrm{BAC}$ variable is not in accordance with the results of the Trujillo-Ponce (2013) which shows that BAC has a positive effect on ROA in microbanks. The negative and significant effect of BAC is in accordance with the results of research by Davydenko (2011) on banks in Ukraine which explains that the negative effect of BAC indicates the low quality of financing at the bank.

Capital structure (CS) shows a positive effect on ROA, but has a negative effect on ROE. The positive effect between CS and ROA is in accordance with the findings of Aslam and Ijaz (2016), Trujillo-Ponce (2013), Yanikkaya et al. (2018), and Yao et al. (2018). Meanwhile, the negative effect of CS on profitability is in accordance with the findings of Sun et al. (2017). Then the level of efficiency (EO) has a negative effect on ROA and ROE. These results are in accordance with the findings of Dietrich and Wanzenried (2011), Trujillo-Ponce (2013), Yao et al. (2018), and Zarrouk et al. (2016). Management's ability to utilize operating income for covering operational costs can increase the profitability of the BPRS. On the other hand, the deposit structure (DS) has a positive effect on the ability of the BPRS to increase ROE. These results support the findings of García-Herrero et al. (2009) and Yao et al. (2018) which statesthat DS has an effect on profitability. The ability of the BPRS to allocate financing to generate income is influenced by the level of funding obtained. The higher the funds, the higher the alternative for the BPRS to channel it to businesses that have potential to generate high income. However, if the BPRS is unable to utilize these funds, the cost of funds will increase, thereby reducing the BPRS net profit.

The ability of a BPRS to utilize funding to be used as financing (FDR) is positively related to ROA and ROE. This situation shows that the bigger the funding, the more opportunities to use the business resources owned by the bank to generate profits. The positive relationship between FDR and profitability shows that the dependence of BPRS on third-party funds in the form of deposits and savings is quite high (Sudarsono, 2017b). These results are in accordance with the research of Majid and Ulina (2020), and Dewi and Sudarsono (2021) which found a positive influence between FDR and profitability. Total funding on assets (DAR) has a positive effect on ROA, but a negative 
effect on ROE. This result is different from Bateni et al. (2014) which found that DAR had no effect on profitability. BPRS funds obtained from third parties will increase the chances of the BPRS to allocate its funds to the productive and consumptive sectors. The situation will grow a potential source of income in order to increase the ratio of income to assets of the BPRS. However, the increase in DAR received a negative response from ROE because the capital of the BPRS did not have a direct impact on DAR that used assets as a weighting of third-party funds.

Economic growth has no effect on the profitability of the BPRS. These results support the research of Fithria (2018) which finds that economic growth has no effect on profitability in BPRS. This condition occurred because the economic growth in the research period was relatively stable and even tended to stagnate so that it did not affect the amount of funding and financing of the BPRS. Meanwhile, the inflation rate has no effect on ROA but has a positive and no effect on ROE. This situation indicates that inflation will cause bank funds to decline, thereby reducing the bank's ability to generate profits. However, rising inflation can encourage increased consumption of goods and services. This situation will increase the ability of producers to meet their financing obligations at banks (Sudarsono, 2017a). These results support the research of Aslam and Ijaz (2016), Chokri and Anis (2018), and Fithria (2018) which find that inflation does not statistically affect bank profitability.

\section{Conclusion}

From the results of the Arrelano test and the Sargan test, the ROA equation models that meet the criteria for consistent estimators and valid instruments are model 1, 4, and 6. From the regression results, it is found that STAB, SIZE, and BAC have a negative effect on profitability. While CS, $\mathrm{OE}$, and DS have no effect on profitability. FDR and DAR show a positive effect on profitability. Meanwhile, GDP and INF have no effect on profitability. Meanwhile, from the ROE equation model, it is known that all models have met the consistency estimator and have valid instruments. STAB, SIZE, CS, EO, and DAR are negatively related to ROE, but model 3 shows that EO does not significantly affect profitability. The effect of $\mathrm{BAC}$ on ROE is different from that on ROA, $\mathrm{BAC}$ has a positive effect on ROE, but equation 2 shows a negative effect. Likewise in DS, the ratio of financing to deposit ratio and INF shows a positive relationship to ROE. Meanwhile, FDR to profitability in the ROE equation model has a similarity with ROA in which GDP has no effect on ROE.

The stability and size of the BPRS proved to have a negative effect on ROA and ROE. These results indicate that the management of the BPRS needs to be open to generating profits consistently through diversification of financing programs. A BPRS that consistently generates profits will make the BPRS more stable and the stability of the BPRS will affect the BPRS in generating profits on an ongoing basis. Meanwhile, bank's management needs to optimize assets through measurable financing. Assets that are not able to be utilized properly will cause over liquidity and increase the cost of funds of the BPRS. Prudence is an integral part of the bank's efforts to avoid financial problems, but systematic efforts are needed in optimizing assets in order to generate optimal profits.

A number of limitations in this study, among others, this study focuses more on the effect of stability and size on the profitability of the BPRS. It is recommended for further research to include the policy variables of the BPRS owner and BPRS management in influencing profitability. Moreover, it is necessary to consider adding macroeconomic variables such as interest rates and investment levels. In addition, this study uses 82 BPRS with a period of 7 years or from 2012 to 2018. It is recommended for future research to use all BPRS and the research period is extended until 2021.

\section{Author Contributions}

Conceptualization: Heri Sudarsono

Data curation: Heri Sudarsono, Fiqih Afriadi

Formal analysis: Heri Sudarsono, Siti Aisiyah Suciningtias 
Investigation: Fiqih Afriadi, Siti Aisiyah Suciningtias

Methodology: Heri Sudarsono, Fiqih Afriadi

Project Administration: Siti Aisiyah Suciningtias

Supervision: Heri Sudarsono

Validation: Heri Sudarsono, Fiqih Afriadi, Siti Aisiyah Suciningtias

Visualization: Fiqih Afriadi, Siti Aisiyah Suciningtias

Writing - original draft: Heri Sudarsono, Fiqih Afriadi

Writing - review \& editing: Heri Sudarsono, Siti Aisiyah Suciningtias

\section{References}

Ahamed, M, M. (2017). Asset quality, non-interest income, and bank profitability: Evidence from Indian banks. Economic Modelling, 63, 1-14. https://doi.org/10.1016/j.econmod.2017.01.016

Ali, M., \& Puah, C. H. (2019). The internal determinants of bank profitability and stability: An insight from banking sector of Pakistan. Management Research Review, 42(1), 49-67. https://doi.org/10.1108/MRR-04-2017-0103

Amanda, M. P., Lam, S., Rinaningsih., \& Adelina, Y. E. (2020). The effect of concentrated ownership on bank profitability in Indonesia. Jurnal Akuntansi dan Kenangan Indonesia, 17(1), 22-42. https://doi.org/10.21002/jaki.2020.02

Arellano, M., \& Bover, O. (1995). Another look at the instrumental variable estimation of errorcomponents models. Journal of Econometrics, 68(1), 29-51. https://doi.org/10.1016/03044076(94)01642-D

Aslam, E., \& Ijaz, F., (2016). Does working capital and financial structure impact profitability of islamic and conventional banks differently?. Islamic Banking and Finance Review, 03, 67-83. https://doi.org/10.32350/ibfr.2016.03.05

Athanasoglou, P. P., Brissimis, S. N., \& Delis, M. D. (2008). Bank-specific, industry-specific and macroeconomic determinants of bank profitability. Journal of International Financial Markets, Institutions and Money, 18(2), 121-136. https://doi.org/10.1016/j.intfin.2006.07.001

Azoury, N., Azouri, A., Bouri, E., \& Khalife, D. (2018). Ownership concentration, ownership identity, and bank performance. Banks and Bank Systems, 13(1), 60-71. https://doi.org/10.21511/bbs.13(1).2018.06

Bateni, L., Vakilifard, H., \& Asghari, F. (2014). The influential factors on capital adequacy ratio in Iranian banks. International Journal of Economics and Finance, 6(11), 108-116. https://doi.org/10.5539/ijef.v6n11p108

Blundell, R., \& Bond, S. (1998). Initial conditions and moment restrictions in dynamic panel data models. Journal of Econometrics, 87, 115-143. Retrieved from https://www.ucl.ac.uk/ uctp39a/Blundell-Bond-1998.pdf

Bougatef, K. (2017). Determinants of bank profitability in Tunisia: Does corruption matter?. Journal of Money Laundering Control, 20(1), 70-78. https://doi.org/10.1108/JMLC-10-2015-0044

Boussaada, R., \& Karmani, M. (2015). Ownership concentration and bank performance: Evidence from MENA banks. International Journal of Business and Management, 10(3), 189-202. https://doi.org/10.5539/ijbm.v10n3p189

Chokri, T., \& Anis, E. A. (2018). Measuring the financial performance of Islamic banks in selected countries. Journal of Business \& Financial Affairs, 07(01). https://doi.org/10.4172/21670234.1000328

Davydenko, A. (2011). Determinants of bank profitability in Ukraine. Undergraduate Economic Review, 7(1), 1-30. Retrieved from https://digitalcommons.iwu.edu/uer/vol7/iss1/2 
Demirgiic, A., \& Huizinga, H. (1999). Determinants of commercial bank interest margins and profitability: Some international evidence. The World Bank. Economic Review, 13(2), 379-408. Retrieved from http://wber.oxfordjournals.org/

Dewi, F. K., \& Sudarsono, H. (2021). Analisis profitabilitas bank syariah di Indonesia: Pendekatan autoregressive distributed lag (ARDL). Al-Mashrafiyah: Jurnal Ekonomi, Kenangan, dan Perbankan Syariah, 5(1), 59. https://doi.org/10.24252/al-mashrafiyah.v5i1.20281

Dietrich, A., \& Wanzenried, G. (2011). Determinants of bank profitability before and during the crisis: Evidence from Switzerland. Journal of International Financial Markets, Institutions and Money, 21(3), 307-327. https://doi.org/10.1016/j.intfin.2010.11.002

Dietrich, A., \& Wanzenried, G. (2014). The determinants of commercial banking profitability in low, middle, and high-income countries. The Quarterly Review of Economics and Finance, 54(3), 337-354. https://doi.org/10.1016/j.qref.2014.03.001

Djalilov, K., \& Piesse, J. (2016). Determinants of bank profitability in transition countries: What matters most?. Research in International Business and Finance, 38, 69-82. https://doi.org/10.1016/j.ribaf.2016.03.015

Fithria, A. (2018). Analisis profitabilitas bank pembiayaan rakyat syariah di Indonesia: Apakah kepemilikan manajemen berpengaruh?. Jurnal Akuntansi dan Bisnis, 18(1), 39. https://doi.org/10.20961/jab.v18i1.232

García-Herrero, A., Gavilá, S., \& Santabárbara, D. (2009). What explains the low profitability of Chinese banks?. Journal of Banking \& Finance, 33(11), 2080-2092. https://doi.org/10.1016/j.jbankfin.2009.05.005

Hapsari, A. \& Rokhim, R. (2017). Foreign ownership and bank performance: Evidence from Indonesia. Jurnal Dinamika Manajemen, 8(1), 30-43. Retrieved from https://journal.unnes.ac.id/nju/index.php/jdm/article/view/10409/6439

Javaid, S., Anwar, J., Zaman, K., \& Ghafoor, A. (2011). Determinants of bank profitability in pakistan: Internal factor analysis. Journal of Yaşar University, 11.

Khan, M. S., Scheule, H., \& Wu, E. (2017). Funding liquidity and bank risk taking. Journal of Banking \& Finance, 82, 203-216. https://doi.org/10.1016/j.jbankfin.2016.09.005

Kosmidou, K., (2008). The determinants of banks' profits in Greece during the period of EU financial integration. Management Finance, 34, 146-159. https://doi.org/10.1108/03074350810848036

Le, T. D. Q. (2020). The interrelationship among bank profitability, bank stability, and loan growth: Evidence from Vietnam. Cogent Business \& Management, 7(1), 1840488. https://doi.org/10.1080/23311975.2020.1840488

Lee, \& Isa. (2017). Determinants of bank margins in a dual banking system. Managerial Finance, 43(6), 630-645. https://doi.org/10.1108/MF-07-2016-0189

Lee, J. Y., Growe, G., DeBruine, M., \& Cha, I. (2015). Measuring the impact of the 2007-2009 financial crisis on the performance and profitability of U.S. regional banks. Advances in Management Accounting, 181-206. https://doi.org/10.1108/s1474-787120150000025005

Lepetit, L., \& Strobel, F. (2015). Bank insolvency risk and Z-score measures: A refinement. Finance Research Letters, 13, 214-224. https://doi.org/10.1016/j.frl.2015.01.001

Majid, M. S. Abd., \& Ulina, S. (2020). Does the 2008-global financial crisis matter for the determinants of conventional and Islamic banking performances in Indonesia? Jurnal Ekonomi and Keuangan Islam, 6(2), 77-90. https://doi.org/10.20885/jeki.vol6.iss2.art1 
Mokni, R. B., Rajhi, M. T., \& Rachdi, H. (2016). Bank risk-taking in the MENA region: A comparison between Islamic banks and conventional banks. International Journal of Social Economics, 43(12), 1367-1385. https://doi.org/10.1108/IJSE-03-2015-0050

Roodman, D. (2009). How to do xtabond2: An introduction to differnce and sytem GMM in Stata. The Stata Journal, 9(1), 86-136. https://doi.org/10.1177/1536867X0900900106

Said, M., \& Ali, H. (2016). An analysis on the factors affecting profitability level of Sharia banking in Indonesia. Banks and Bank Systems, 11(3), 28-36. https://doi.org/10.21511/bbs.11(3).2016.03

Sijabat, Y. P., Sinabutar, M. J., Hirawati, H., \& Giovanni, A. (2020). The determination of concentration and type of ownership on bank performance and risks in Indonesia. Society, 8(1), 191-203. https://doi.org/10.33019/society.v8i1.152

Sinha, P., \& Sharma, S. (2016). Determinants of bank profits and its persistence in Indian Banks: A study in a dynamic panel data framework. International Journal of System Assurance Engineering and Management, 7(1), 35-46. https://doi.org/10.1007/s13198-015-0388-9

Sudarsono, H. (2017a). Analisis efektifitas transmisi kebijakan moneter konvensional dan syariah dalam mempengaruhi tingkat inflasi. Jurnal Ekonomi dan Kenangan Islam, 3(2), 53-64. https://doi.org/10.20885/jeki.vol3.iss2.art1

Sudarsono, H. (2017b). Modelling respon rasio keuangan terhadap pembiayaan pada bank syariah di Indonesia. Jurnal Ekonomi Syariah Indonesia, 7(1), 1-13. https://doi.org/10.21927/jesi.2017.7(1).1-13

Sun, P. H., Mohamad, S., \& Ariff, M. (2017). Determinants driving bank performance: A comparison of two types of banks in the OIC. Pacific-Basin Finance Journal, 42, 193-203. https://doi.org/10.1016/j.pacfin.2016.02.007

Tan, Y. (2016). The impacts of risk and competition on bank profitability in China. Journal of International Financial Markets, Institutions and Money, 40, 85-110. https://doi.org/10.1016/j.intfin.2015.09.003

Tan, Y., \& Floros, C. (2012). Bank profitability and inflation: The case of China. Journal of Economic Studies, 39(6), 675-696. https://doi.org/10.1108/01443581211274610

Trujillo-Ponce, A. (2013). What determines the profitability of banks? Evidence from Spain. Accounting \& Finance, 53(2), 561-586. https://doi.org/10.1111/j.1467-629X.2011.00466.x

Tumewang, Y. K., Isnaini, R. N., \& Musta'in, J. L. (2019). The impact of macro economy toward profitability of Islamic bank. Asian Journal of Islamic Management (AJIM), 1(2), 101-108. https://doi.org/10.20885/ajim.vol1.iss2.art4

Westman, H. (2011). The impact of management and board ownership on probabilitity in banks with different strategies. Journal of Banking \& Finance, 35, 3300-3318

Widarjono, A. (2018). Estimating profitability of Islamic banking in Indonesia. Jurnal Keuangan dan Perbankan, 22(3), 568-570. https://doi.org/10.26905/jkdp.v22i3.2197

Windmeijer, F. (2005). A finite sample correction for the variance of linear efficient two-step GMM estimators. Journal of Econometrics, 126(1), 25-51. https://doi.org/10.1016/j.jeconom.2004.02.005

Yanikkaya, H., Gumus, N., \& Pabuccu, Y. U. (2018). How profitability differs between conventional and Islamic banks: A dynamic panel data approach. Pacific-Basin Finance Journal, 48, 99-111. https://doi.org/10.1016/j.pacfin.2018.01.006

Yao, H., Haris, M., \& Tariq, G. (2018). Profitability determinants of financial institutions: Evidence from banks in Pakistan. International Journal of Financial Studies, 6(2), 1-28. https://doi.org/10.3390/ijfs6020053 
Yudha, A., Chabachib, M., \& Pangestuti, I. R. D. (2017). Analysis of the effect of NPL, NIM, non interest income, and LDR toward ROA with size as control variables (Differences study on domestic and foreign banks listed on BEI period 2010-2015). Jurnal Bisnis Strategi 26(2), 100-113. Retrieved from https://ejournal.undip.ac.id/index.php/jbs/article/viewFile/15175/12420

Zarrouk, H., Ben Jedidia, K., \& Moualhi, M. (2016). Is Islamic bank profitability driven by same forces as conventional banks? International Journal of Islamic and Middle Eastern Finance and Management, 9(1), 46-66. https://doi.org/10.1108/IMEFM-12-2014-0120

Zouari, S. B. S., \& Taktak, N. B. (2014). Ownership structure and financial performance in Islamic banks: Does bank ownership matter?. International Journal of Islamic and Middle Eastern Finance and Management, 7(2), 146-160. https://doi.org/10.1108/IMEFM-01-2013-0002 